\title{
"Risk perception and psychological behavior of investors in emerging market: Indonesian Stock Exchange"
}

\begin{tabular}{|c|c|}
\hline AUTHORS & $\begin{array}{l}\text { Yuliani } \\
\text { Isnurhadi } \\
\text { Ferry Jie (D) https://orcid.org/0000-0002-6287-8471 }\end{array}$ \\
\hline ARTICLE INFO & $\begin{array}{l}\text { Yuliani, Isnurhadi and Ferry Jie (2017). Risk perception and psychological } \\
\text { behavior of investors in emerging market: Indonesian Stock Exchange. } \\
\text { Investment Management and Financial Innovations, 14(2-2), 347-358. } \\
\text { doi:10.21511/imfi.14(2-2).2017.06 }\end{array}$ \\
\hline DOI & http://dx.doi.org/10.21511/imfi.14(2-2).2017.06 \\
\hline RELEASED ON & Saturday, 19 August 2017 \\
\hline RECEIVED ON & Tuesday, 14 February 2017 \\
\hline ACCEPTED ON & Monday, 26 June 2017 \\
\hline LICENSE & $\begin{array}{l}(c) \text { EY-NG } \\
\text { This work is licensed under a Creative Commons Attribution-NonCommercial } 4.0 \\
\text { International License }\end{array}$ \\
\hline JOURNAL & "Investment Management and Financial Innovations" \\
\hline ISSN PRINT & $1810-4967$ \\
\hline ISSN ONLINE & $1812-9358$ \\
\hline PUBLISHER & LLC "Consulting Publishing Company "Business Perspectives" \\
\hline FOUNDER & LLC "Consulting Publishing Company "Business Perspectives" \\
\hline
\end{tabular}

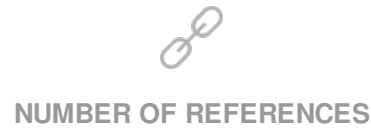

32
NUMBER OF FIGURES

1
NUMBER OF TABLES

11

(C) The author(s) 2022. This publication is an open access article. 


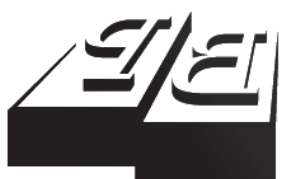

BUSINESS PERSPECTIVES

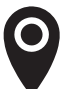

LLC "CPC "Business Perspectives" Hryhorii Skovoroda lane, 10, Sumy, 40022, Ukraine

www.businessperspectives.org

Received on: $14^{\text {th }}$ of February, 2017 Accepted on: $26^{\text {th }}$ of June, 2017

C) Yuliani, Isnurhadi, Ferry Jie, 2017

Yuliani, Ph.D., Universitas Sriwijaya, Indonesia.

Isnurhadi, Ph.D., Universitas Sriwijaya, Indonesia.

Ferry Jie, Associate Professor, Edith Cowan University, Australia.

\section{(ㄷ)(1) $(8)$}

This is an Open Access article, distributed under the terms of the Creative Commons Attribution-NonCommercial 4.0 International license, which permits re-use, distribution, and reproduction, provided the materials aren't used for commercial purposes and the original work is properly cited.
RISK PERCEPTION AND

PSYCHOLOGICAL BEHAVIOR OF INVESTORS IN EMERGING MARKET: INDONESIAN STOCK EXCHANGE

\begin{abstract}
Capital market functions as a mediator between parties who have excess funds that is, investors and those who need the funds that is, emitents. Decision to sell and buy shares of a financial asset is very strategic decision for investors because it is associated with the chances of return to be earned in the future. The objective of this paper is to investigate the investor's psychology on buying and selling common stock in the stock exchange in emerging market. The specific purpose of this research is to provide the simultaneous empirical evidence about the perception of risk, psychology aspects towards the confidence and performance. The sample consists of 100 individual investors in Palembang, South Sumatera, Indonesia. The data were collected during March-May 2016 using questionnaire. Research findings show that perception of risk and psychology significantly affect confidence. Furthermore, confidence has a significantly positive impact on performance. This research has not been explained entirely towards the investor's psychological behavior aspects, so the additional variable may be needed as the full reflection of investor's psychology. The further research may use experimental study, starts from buying stocks, and factors that can be considered in selling stock.
\end{abstract}

\section{Keywords} confidence, perception of risk, psychology, performance

\section{JEL Classification G11, G12}

\section{INTRODUCTION}

The role of capital market in a country is related with capital flow and economic growth. Indonesia's economic growth requires funding and a sizeable investment to be able to compete regionally and globally. The number of issuers, Composite Stock Price Index, amount of outstanding shares and a market capitalization fluctuates and shows improvement for the last two years, 2015 and 2014. In addition, the amount of outstanding shares fluctuates as well and tends to decline by $9.06 \%$, but the value of market capitalization increases by $23.92 \%$ (www.idx.co.id, 2014). The increasing number of issuers improves capital market performance so as to open opportunity for investors to increase their investment activities. Decision of investors to use capital market for investment activities is classified as financial assets. The behavior of investors to buy and sell financial assets is a strategic decision, because it is related to the return they gain. The individual investor's behavior in investment decision on financial assets is something interesting to study.

Based on the number of shares owned by the investor, it was found in the study by Barber and Odean (2001) with sample by 78,000 investors in the US that the average number of shares held is 2 and 3 and the 
percentage of investors who are able to earn returns above the market index is $49.3 \%$. In the previuous year, Barber and Odean (2000) conducted a study using household investors as the respondents covering 35,000 investors for six years. This study found that male investors make transactions $45 \%$ more often than female investors, even the single male investors transacted $67 \%$ more frequently than that of single female investors. The interesting finding of this study is that due to the different trading frequency, male investors' net profit reduced as much as $2.5 \%$, while only $1.72 \%$ for female investors. This difference indicates that the female investor', ultimately, are more prosperous than male investors. Talar (2004) found that the dominant factors affecting the decisions of daily stock transaction are technical, foreign investors, stock liquidity, as well as rumors.

The purpose of this study is to examine the influence of risk perception on investors' confidence in the stock exchange, to explain the influence of psychological factor on investors' confidence and explain the effect of stock market confidence on the stock performance.

\section{THEORIES AND HYPOTHESES}

Investing is simply defined as placement of money or funds with the hope to obtain additional money or funds. Investment is also defined as the commitment of a number of funds to one or more assets to be held for some time to come. Investment as a commitment to the number of funds or other resources is done at this time with the aim to make a profit in the future (Salge et al., 2015; Linnenluecke et al., 2016).

From the above definition of investment, it can be inferred that investment consists of three elements, namely expense or sacrifice of resources at the present, then, an element of risk uncertainty and return in the future. Someone who invests has different motives. For instance, to meet liquidity needs, to save for retirement, to speculate and so on. Investments can be classified into two categories: investment in real assets, namely the tangible fixed assets and another category is investment in financial assets. This research focuses on the study of financial assets in the form of marketable securities traded in the organized market/stock exchange.

Types of investors are described in the studies by Grinblatt and Keloharju (2001), Hui and Li (2014). All investors can be classified into three: (1) a conservative investor, the type of investors who tend to avoid risks, play in investment instruments and low risk, (2) moderate investors, namely investors who have high levels of tolerance for higher risk with commensurate results, (3) an aggressive investor, that is, an investor who hase high risk tolerance level, with the principle of high risk return even at extreme scale. This type of investor can be viewed as a speculator. In addition, traders are classified into five, namely: scalpers, day traders, swing traders, position traders and investors. The differences of type of trader are shown in Table 1.

Behavioral finance is studied to explain the market inefficiencies using psychological theories. In practice, it is observed that an individual oftentimes makes mistakes and illogical assumption

Table 1. Type of traders

\begin{tabular}{|c|c|c|c|c|c|}
\hline Type of trader & Scalper & Day trader & Swing trader & Position trader & Investor \\
\hline Trading style & Aggressive & Aggressive & Aggressive enough & Passive & Passive \\
\hline Trading total & Many & Many & Many enough & Few & Few \\
\hline Time frame & $\begin{array}{l}\text { Very short } \\
\text { (min-hour) }\end{array}$ & Short (min-hour) & Long (day-week) & $\begin{array}{l}\text { Longer } \\
\text { (week-month) }\end{array}$ & $\begin{array}{l}\text { Very long } \\
\text { (month-year) }\end{array}$ \\
\hline Chart & Tick-M5 & M15-H1 & H4-D1 & D1-W1 & W1-Month1 \\
\hline
\end{tabular}


when dealing with financial matters. The emergence of behavioral finance begins when Shiller, a professor from Yale University, wrote a working paper titled "Irrational Exuberance". Shiller warned investors that stock price based on various historical measurements will rise too high, and public will be very disappointed with the performance of stocks in the future. This is proved by the decrease of stock prices shortly after a warning from Shiller.

Behavioral finance is still a new paradigm in the research fields of finance, which provides a supplement to standard finance theory by introducing the behavioral aspects of the decision. In contrast to the approach of Markowitz and Sharpe, behavioral finance approved the way people use information. Behavioral finance try to find and predict the implications of the financial markets on a systematic psychological decision processes so that the focus is on the application of economic principles for financial decision making (Barberis \& Thaler, 2001; Singh et al., 2003; Du, 2012).

Topics in behavioral finance consist of: (1) Behavioral Microfinance (BFM), which examines the behavior or biases of individual investors that distinguish them from rational individual as in classical economic theory, (2) Behavioral Macrofinance (BFM) to detect and describe anomalies in the efficient market hypothesis described in the model behavior. This study focused on BFMI, the study of the behavior of individual investors, in order to identify psychological biases and investigate the behavior of the asset allocation decision so as to reduce bias in the investment process.

Lucey (2005) conducted a survey on the influence of the feeling of investors in equity prices and also developed the theory to explain the emergence of the findings in this area. This study examines the impact of environmental factors such as weather, biorhythms of the body, and social factors that affect the image of the mood of investors that has an impact on investment decisions. The research findings are: (1) investors invest in a manner which is consistent with their feelings, (2) feelings' effect on equity prices, (3) the weather, biological cycle of the body, disruption of sleep patterns, the lunar phases, social activities and the effect of mood on decision-making.

Furthermore, Worhington (2006) examined the relationship between weather and mood and feeling for Australian investors in the capital market during the period 1958-2005. Eleven elements of weather were inserted, i.e., precipitations, evaporation, relative humidity, temperature maximum and minimum, average temperature daily, hours of sun shine, wind speed and direction, average daily wind speed to real and nominal market return. Using non-parametric correlation analysis and autoreggresive moving average models, the findings of this study show that weather factors do not affect market return.

Another study conducted by Durand and Sanghani (2008) examined the relationship between personality and investment decisions and portfolio performance. The sample consisted of 18 individual investors who hold equity portfolios in Australia for the financial year ended 30 June 2005. The findings of the study include: (1) individuals who are more extrovert and less masculine have a greater preference for innovation and achieve superior portfolio performance, (2) individuals who have higher negative emotions tend to take higher risk and more often to choose higher risk portfolio, (3) the higher negative emotions of individuals who have a tendency of taking higher risks are also related to increase in trading behavior, while investors who are more extrovert were found to have a lower tendency toward trading behavior and (4) the role of psychological gender is better than the biological gender in analyzing the investors behavior.

Several studies in Indonesia were conducted by Natapura (2009), Kartika and Iramani (2013), Wulandari and Iramani (2014) with respondents in Surabaya and showed that the factors considered by investors in investing in the stock market is a source of neutral information, accounting information, and demographic. In data addition, some factors such as risk perception, confidence factor, the experience and psychological factors also emerged as the decisive factor for stock investment decisions. The study by Maulina (2011) on the information asymmetry and period of ownership of ordinary shares on the stock exchange 


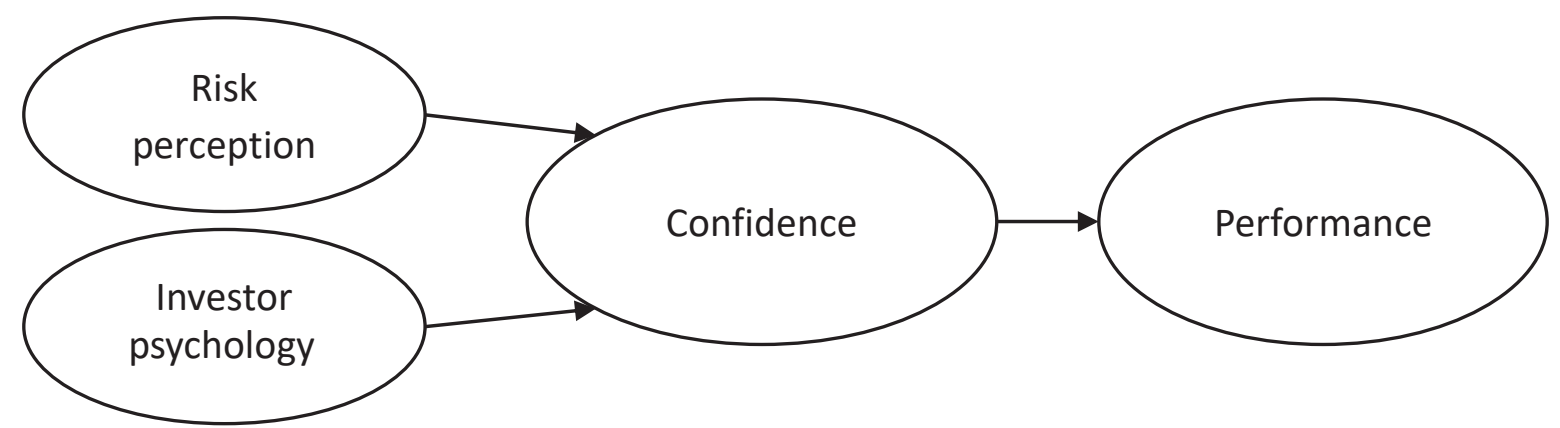

Figure 1. Research model

using the method of path analysis showed that the average investor holding ordinary shares for two years and, in general, all investors are more oriented towards short-term investments with the expected capital gains rather than dividends. Research on fundamental variables in predicting stock return is done by Yanti (2012) on the object of observation shares of Shariah in Indonesian Stock Exchange. Using path analysis found that the investment strategy of the investors in the shares of Shariah is a priority to fundamental information Price Earnings Ratio (PER) and stock return. Based on the description above, the model of the research hypotheses as follows:

Based on Figure 1, hypotheses of this research are:

H1: Risk perception has a significant effect on stock market confidence.

H2: Investor psychology has a significant effect on stock market confidence.

H3: Confidence in stock market has a significant effect on stock market performance.

\section{METHODOLOGY}

\subsection{Data and operational variable}

Data used in this research are primary data obtained by using a questionnaire. Purposive sampling is used to identify respondents based on these criteria: (1) investors are still active in trading common stock, (2) investors have been involved in capital market as investors for at least two years, (3) investors are not directly involved in the government strategic decision making or as government officials. The analytical unit of this research is individual investor. The data collection period is three months (March-May, 2016). Data collection was performed using questionnaires and direct interviews. The result is 100 valid data.

The variables used in this study are divided into exogenous and endogenous. Exogenous variables consist of risk perception, the psychology of investors, confidence in capital markets, while the endogenous variable is the performance of common stock. To measure the variables, Likert scale was employed. The scale includes an interval of 1

Table 2. Operational variable research

\begin{tabular}{|c|c|c|c|}
\hline No & Variable & Indicators & Source \\
\hline \multicolumn{4}{|c|}{ Exogenous } \\
\hline 1. & Risk perception of stock & $\begin{array}{l}\text { Risk averse } \\
\text { Risk taker } \\
\text { Moderate }\end{array}$ & Barber and Odean (2000), Frensidy (2013), Bayar (2013) \\
\hline 2. & Investor psychology & $\begin{array}{l}\text { Cognative } \\
\text { Cognitive } \\
\text { Affective }\end{array}$ & $\begin{array}{l}\text { Grinblatt and Keloharju (2009), Qawi (2010), } \\
\text { Bayar (2013) }\end{array}$ \\
\hline 3. & Stock market confidence & $\begin{array}{l}\text { Financial and accounting } \\
\text { information } \\
\text { Media } \\
\text { Friend }\end{array}$ & $\begin{array}{l}\text { Gumanti (2009), Chandra and Kumar (2012), } \\
\text { Bayar (2013) }\end{array}$ \\
\hline \multicolumn{4}{|c|}{ Endogenous } \\
\hline 4. & Stock market performance & $\begin{array}{l}\text { Capital gain } \\
\text { Dividend }\end{array}$ & Bodie et al. (2013) \\
\hline
\end{tabular}


to 5, which comprises: Strongly Disagree (score 1); Disagree (score 2); Normal (score 3); Agree (score 4) and Strongly Agree (score 5). The operational definition of each variable is presented in Table 2 below.

\subsection{Data analysis}

The instrument to collect data in this study was a questionnaire prepared using 5-point Likert scale. The quesionaires have been tested for validity and reliability. Validity test is to determine whether the instrument meets the requirements of the validity of each variable by using the Pearson product moment. The research instrument is valid if the value of validity is $r \geq 0.3$ and significance of the correlation value is $\leq 95 \%$ or $\alpha=0.05$ and $\alpha=0.01$. Realibility test is to look at the consistency of respondents to the question items. The test is done by looking at the Cronbach's alpha coefficient with the limit value (cut of points) feasible being $\geq 0.6$.

This study uses Structural Equation Model (SEM) based component or variance which is noted for as Partial Least Square (PLS). The reason using PLS is as follows: (a) there are more than one variable, namely the perception of risk, investors psychology; investor confidence and stock market performance; (b) involving latent variables, where variables analyzed are unobservable; (c) the model is recursive; (d) the relationship formed is causality.

Furthermore, the hypothesis were tested by using the following steps: 1) assuming linearity test, 2) outer model test (measurement model), 3) Goodness of Fit inner structural model in form PLS Q-square predictive value relevance $\left(Q^{2}\right)$ which is calculated based on the value of $R^{2}$. Magnitude $Q^{2}$ has a value range of $0<Q^{2}<1$, where 1 means that the closer model, the better. $Q^{2}$ calculations performed by the formula:

$$
Q^{2}=1-\left(1-R_{1}^{2}\right) \cdot\left(1-R_{2}^{2}\right) \ldots\left(1-R_{p}^{2}\right),
$$

where

Stock market performance $=$

$=a+\beta_{1}$ risk perception +

$+\beta_{2}$ investor psychology $+\varepsilon$;

Stock market performance $=$ $=a+\beta_{3}$ stock market confidence $+\varepsilon$.

\section{EMPIRICAL RESULTS}

100 quesionares were collected from the respondents (investors) in Palembang during April-June 2016. The demographic data of the investors are shown in Table 3.

According to Table 3, the gender is $63 \%$ males and $37 \%$ females. Male investors are more dominant, since the reference rate in financial assets is less for women to become an investor. The age of investors ranges from $20-25$ years old, and 62 people are single. 77 people have an undergraduate education level, six people have a high school diploma and 17 people have a master degree. According to this frequency, there is something interesting because as many as 20 respondents do not trade regularly in short period of time, meaning that the investors have a long-term goal which is called dividend yield orientation.

The perception of risk of investors falls into three categories, that is, risk averse, risk moderate and risk taker. The risk perception of investors in Palembang is showed in Table 4. From the table, it can be seen that the index of risk perception value on average is $51.94 \%$, while the risk moderate is on average 3.73 . The findings show that investors in Palembang dislike risk, but want high return.

Investor's phychology is reflected in three indicators, namely cognitive, affective and cognative. Table 5 shows the variables describing investor's psychology where cognative indicator is dominant on average of 3.72 . It is clear that investors in Palembang in investing in financial assets have a target return that will be obtained and the risk is to be faced, while the dominant items are the reflection of cognative indicators. Investors in Palembang are satisfied with investing in the stock market, because it can give space to invest, as well manage alternative funds. The results show that investor psychology based on perception index is $77.84 \%$ which is high with mean of 3.45 . The high perception index indicates that investors in Palembang are optimistic in response to a statement on the psychology of being an investor.

Stock market confidence is a reflection of the level of return obtained in the purchase and sale of shares. This variable measures the motivation of 
Table 3. Respondents' demography description

\begin{tabular}{|c|c|c|c|c|}
\hline \multicolumn{2}{|c|}{ Demography description } & \multirow{2}{*}{$\frac{\mathbf{N}}{63}$} & \multirow{2}{*}{$\frac{\text { Valid (\%) }}{63.0}$} & \multirow{2}{*}{$\frac{\text { Cumulative }(\%)}{63.0}$} \\
\hline & Men & & & \\
\hline Gender & Women & 37 & 37.0 & 100.0 \\
\hline \multirow{4}{*}{ Age } & $<20-25$ & 35 & 35.0 & 35.0 \\
\hline & $26-30$ & 31 & 31.0 & 66.0 \\
\hline & $31-35$ & 11 & 11.0 & 77.0 \\
\hline & $36-40$ & 23 & 23.0 & 100.0 \\
\hline \multirow{7}{*}{ Job } & Civil servant & 2 & 2.0 & 2.0 \\
\hline & Private employees & 31 & 31.0 & 33.0 \\
\hline & Privatized employees & 47 & 47.0 & 80.0 \\
\hline & Housewife & 2 & 2.0 & 82.0 \\
\hline & Entrepreneur & 7 & 7.0 & 89.0 \\
\hline & College student & 4 & 4.0 & 93.0 \\
\hline & Other & 7 & 7.0 & 100 \\
\hline \multirow{3}{*}{ Education } & Diploma & 6 & 6.0 & 6.0 \\
\hline & Bachelor & 77 & 77.0 & 83.0 \\
\hline & Master & 17 & 17.0 & 100.0 \\
\hline \multirow{2}{*}{ Marital status } & Married & 38 & 38.0 & 38.0 \\
\hline & Single & 62 & 62.0 & 100.0 \\
\hline \multirow{4}{*}{ Frequency trading } & Every day & 27 & 27.0 & 27.0 \\
\hline & Every week & 28 & 28.0 & 55.0 \\
\hline & Each month & 25 & 25.0 & 80.0 \\
\hline & Do nothing & 20 & 20.0 & 100.0 \\
\hline
\end{tabular}

an investor in the capital market. Measurement of this variable is reflected by three indicators of accounting and financial information, information from the media and the recommendation of friends. The description of the respondents for these variables is shown in Table 5. The dominant indicator of this variable is the accounting and fi- nancial information with the amount of the average 3.42. The results of this description suggest that investors in Palembang, before making a purchase and sale of common stock, will pay attention to the company's fundamental information that is most often done using the company's financial report data source.

Table 4. Risk perception of investors

\begin{tabular}{|c|c|c|c|c|c|c|c|}
\hline \multirow{2}{*}{ Variables } & \multirow{2}{*}{ Items } & \multicolumn{5}{|c|}{ Responses (\%) } & \multirow{2}{*}{ Mean } \\
\hline & & 1 & 2 & 3 & 4 & 5 & \\
\hline SA1 & Price rise in the future & 2 & 7 & 18 & 54 & 19 & 3.81 \\
\hline SA2 & On target & 2 & 6 & 20 & 57 & 15 & 3.77 \\
\hline SA3 & Large company & 1 & 12 & 23 & 38 & 26 & 3.76 \\
\hline SA4 & Short-term orientation & 8 & 26 & 26 & 31 & 9 & 3.07 \\
\hline SA5 & Avoid risk & 5 & 36 & 27 & 27 & 5 & 2.91 \\
\hline \multicolumn{7}{|c|}{ Risk averse (5 items) } & 3.46 \\
\hline RT1 & Not see micro and macro-economic & 25 & 54 & 8 & 10 & 3 & 2.12 \\
\hline RT2 & Expectations of high return & 4 & 21 & 30 & 31 & 14 & 3.29 \\
\hline RT3 & Speculation & 2 & 17 & 38 & 34 & 9 & 3.31 \\
\hline RT4 & Reject low return & 2 & 19 & 22 & 40 & 17 & 3.51 \\
\hline \multicolumn{7}{|c|}{ Risk taker (4 items) } & 3.06 \\
\hline $\mathrm{AB} 1$ & Rational thinking and careful & 3 & 2 & 20 & 50 & 25 & 3.92 \\
\hline $\mathrm{AB} 2$ & Gathering information & 0 & 10 & 23 & 39 & 28 & 3.85 \\
\hline $\mathrm{AB} 3$ & Return as risk balance & 1 & 5 & 22 & 51 & 21 & 3.86 \\
\hline $\mathrm{AB} 4$ & Small risk & 1 & 8 & 41 & 42 & 8 & 3.48 \\
\hline $\mathrm{AB} 5$ & Long-term return & 0 & 22 & 28 & 34 & 16 & 3.44 \\
\hline $\mathrm{AB} 6$ & Price as a reflection of information & 0 & 5 & 25 & 51 & 19 & 3.84 \\
\hline \multicolumn{7}{|c|}{ Risk moderate (6 items) } & 3.73 \\
\hline
\end{tabular}

Note: Average risk perception of stock (x): $51.94 \%$ with mean 3.42 . Intepretation index value is $10-40 \%=$ Low; $41-70 \%=$ Average; $71-100 \%=$ High . 
Table 5. Responses to stock market confidence

\begin{tabular}{|c|c|c|c|c|c|c|c|}
\hline \multirow{2}{*}{ Variables } & \multirow{2}{*}{ Indicators } & \multicolumn{5}{|c|}{ Responses (\%) } & \multirow{2}{*}{ Mean } \\
\hline & & 1 & 2 & 3 & 4 & 5 & \\
\hline AK1 & Financial report & 2 & 15 & 40 & 35 & 8 & 3.32 \\
\hline AK2 & Financial ratios & 0 & 15 & 28 & 40 & 17 & 3.59 \\
\hline AK3 & Fundamental analysis & 2 & 12 & 34 & 35 & 17 & 3.53 \\
\hline AK4 & Technical analysis & 5 & 22 & 31 & 30 & 12 & 3.22 \\
\hline \multicolumn{7}{|c|}{ Financial and accounting information ( 4 items) } & 3.42 \\
\hline MD 1 & Reading newspaper and magazine & 3 & 22 & 34 & 33 & 8 & 3.21 \\
\hline MD2 & Hearing and watching TV & 5 & 17 & 44 & 24 & 10 & 3.17 \\
\hline \multicolumn{7}{|c|}{ Media (2 items) } & 3.19 \\
\hline TM1 & Asking for family & 1 & 24 & 38 & 32 & 5 & 3.16 \\
\hline TM2 & Discussing with friend & 3 & 19 & 32 & 37 & 9 & 3.30 \\
\hline TM3 & Recommendation from friend & 2 & 22 & 39 & 29 & 8 & 3.19 \\
\hline TM4 & Discussing with expert & 2 & 8 & 30 & 37 & 23 & 3.71 \\
\hline \multicolumn{7}{|c|}{ Friend ( 4 items) } & 3.34 \\
\hline
\end{tabular}

Note: Average stock market confidence (x): $33.40 \%$ with mean 3.32 . Intepretation index value is $10-40 \%=$ Low; $41-70 \%=$ Average $; 11-100 \%=$ High .

Table 5 shows that average stock market confidence is $33.40 \%$ with mean 3.32 . These findings suggest that investors in Palembang fall into the category of lower index value. This indicates that the low level of confidence in the financial asset is associated with stocks. The previous variables of risk perception of moderate risk are correlated with low level of confidence of investors in Palembang.

Stock market performance is the response of investors in the capital market. Stock market per- formance in this study is reflected by indicators of capital gains and dividend periodically. Capital gain is measured by three items, namely, stock prices continuing to rise, constantly monitoring prices and make purchases on a daily basis and orientation to the stock price. Based on these three items, the stock price increases have the highest response from investors in Palembang.

Indicator shows that the distribution of profit as dividend obligations to the company's shareholders on average is 3.50 . Referring to the average

Table 6. Responses to stock market performance

\begin{tabular}{|c|c|c|c|c|c|c|c|}
\hline \multirow{2}{*}{ Variables } & \multirow{2}{*}{ Indicators } & \multicolumn{5}{|c|}{ Responses (\%) } & \multirow{2}{*}{ Mean } \\
\hline & & 1 & 2 & 3 & 4 & 5 & \\
\hline CG1 & Increasing stock price & 1 & 9 & 18 & 41 & 31 & 3.92 \\
\hline CG2 & Look and buy every day & 1 & 16 & 33 & 34 & 16 & 3.48 \\
\hline CG3 & Stock price orientation & 0 & 14 & 29 & 41 & 16 & 3.59 \\
\hline \multicolumn{7}{|c|}{ Capital gain (3 items) } & 3.66 \\
\hline DV1 & Long-term goal & 4 & 10 & 34 & 32 & 20 & 3.54 \\
\hline DV2 & Profit dividend & 4 & 9 & 28 & 48 & 11 & 3.53 \\
\hline DV3 & Cash dividend & 2 & 12 & 32 & 31 & 23 & 3.61 \\
\hline DV4 & Profit growth & 2 & 16 & 40 & 31 & 11 & 3.33 \\
\hline \multicolumn{7}{|c|}{ Dividend (4 items) } & 3.50 \\
\hline
\end{tabular}

Note: Average stock index performance (x): $25.00 \%$ with mean 3.58. Intepretation index value is $10-40 \%=$ Low; $41-70 \%=$ Average; $71-100 \%=$ High. 
Table 7. Descriptive statistics ( $N=100)$

\begin{tabular}{|c|c|c|c|c|}
\hline Variable & Min & Max & Mean & $\begin{array}{l}\text { Standard } \\
\text { deviation }\end{array}$ \\
\hline Risk perception & 2.730 & 4.470 & 3.463 & 0.396 \\
\hline Investor's psychology & 1.500 & 6.630 & 3.459 & 0.545 \\
\hline Confidence & 2.000 & 4.600 & 3.340 & 0.621 \\
\hline Performance & 2.430 & 5.000 & 3.571 & 0.541 \\
\hline
\end{tabular}

perception index it can be concluded that the responses of investors in Palembang in buying and selling stock is low at $25 \%$ with the average of 3.58 . These findings indicate that the investors are oriented towards capital gain.

Descriptive statistic of the data is important to see data distribution. Table 7 shows that the lowest value of the variable risk perception is 2.73 and the highest is 4.47 with mean of 4.463 and standard deviation of 0.396 . The standard deviation value which is smaller than mean indicates that the data are spread evenly so that it can otherwise be normal. The difference between the highest value and the lowest due to the characteristics of each respondent is different and can be seen from the respondents age of $35 \%$ or $<20-25$ years. This can affect the perception risk of investing in stocks that a high level of risk.

Investor's psychology, which is reflected by three indicators, namely, cognitive, affective and cognative shows the highest value of 6.63 , the lowest 1.50, mean and standard deviation of 4.56 and 0.55 . The average value is greater than standard deviation and indicates that the data are normally distributed so that it can be stated that there are discrepancies among respondents with respect to the perception of the psychology of knowledge about the capital market, the target return and risk and emotional factors. Stock market confidence shows investors' perceptions in gathering information to analyze the decision of buying and selling shares. The lowest value of this variable is 2.0 and the highest 4.6 indicating that respondents have different perceptions toward accounting and financial information, gathering information from the media and asking for a favor from their friends.

Stock market performance is reflected in the amount of capital gain and dividends and shows the desire of investors on financial assets. The lowest value is 2.43 , the highest is 5.0 , the mean is 3.57 and the standard deviation is 0.54 . Capital gain reflects the difference between the purchase price and selling price of shares. The higher this difference, the higher stock performance and investor expectations. Dividend is a shareholder right so that long-term investors will look at the fundamentals of companies in various aspects. The most aspect is the growth of sales and profit growth.

The was conducted important by using a questionnaire to determine the reliability and validity. If valid and reliable, the can be used for testing the hypotheses that have been proposed. The reliability test results are shown in Table 8 .

Testing instruments seen from the magnitude Average Variance Extracted (AVE) show greater than 0.05. It appears that all variables are accepted. Reliability test by Tucker and Levi based on

Table 8. The result of the test reliability

\begin{tabular}{l|c|c|c}
\multicolumn{1}{c}{ Variables } & AVE & Composite reliability & Cronbach's alpha \\
\hline Risk perception & 0.216 & 0.640 & 0.675 \\
\hline Investor's psychology & 0.319 & 0.841 & 0.820 \\
\hline Confidence & 0.417 & 0.728 & 0.841 \\
Performance & 0.289 & 0.640 & 0.621 \\
\hline
\end{tabular}


Table 9. The result of test validity

\begin{tabular}{|c|c|c|c|c|}
\hline \multirow{2}{*}{ Variables } & \multicolumn{4}{|c|}{ Correlation } \\
\hline & Risk perception & Investor's psychology & Confidence & Performance \\
\hline Risk perception & 1.000 & - & - & - \\
\hline Investor's psychology & 0.229 & 1.000 & - & - \\
\hline Confidence & 0.528 & 0.518 & 1.000 & - \\
\hline Performance & 0.487 & 0.404 & 0.536 & 1.000 \\
\hline
\end{tabular}

composite reliability shows that all the variables is reliable. In addition, the value of Cronbach's alpha with the provisions of 0.7 to 0.5 is still acceptable meaning that the instrument used is reliable. From Table 8 , it is seen that highest value of Cronbach's alpha is investor's psychology. It means that the reliability of each item in the statement is consistently reflected in the studied variables. The indicators of investor's psychology variables in this study consist of cognitive, affective and cognative and, so, are called the three important things for an investor in the buying and selling shares in the capital market. Testing discriminant validity is conducted by looking at the correlation between variables. Validity of a variable will be indicated by high value correlation. The high correlation value reflects that the research instrument is valid. Table 9 shows that the correlation between variables is so high that it can be concluded that the instruments are valid.

Testing linearity in this study is done using a curve fit with reference to the principle of parsimony. Table 10 above shows that all the relationship between variables are linear and all models are significant. Based on the linearity test results, it can be stated that the relationship between each independent variable is linear towards the dependent variable. This linearity assumption test results will be used to continue the test of the hypotheses. The higher the value of $Q^{2}$, the better research model is used to predict performance. Table 10 shows the value of 0.605 meaning that the model is still considered good enough to predict the performance as much as by $60.5 \%$. Another $30.5 \%$ of other variables outside the model can still be used to predict performance.

The recapitulation hypotheses test results are shown in Table 11.

Table 11 shows that all the hypotheses are accepted. They indicate that investors in Palembang in investing are financial assets, all items of the research intruments are well explained. Theoretically all variables used in this study based on the concept of behavioral finance will be a strong concept to predict the stock market performance.

Table 10. Linearity assumption

\begin{tabular}{|c|c|c|c|c|}
\hline Independent variable & Dependent variable & Result $(\alpha=0.05)$ & Sig & Decision \\
\hline Risk perception & \multirow{2}{*}{ Confidence } & All models are significant & 0.001 & Linear \\
\hline Investor's psychology & & All models are significant & 0.047 & Linear \\
\hline Confidence & Performance & All models are significant & 0.000 & Linear \\
\hline
\end{tabular}

Table 11. The result of hypotheses research

\begin{tabular}{|c|c|c|c|}
\hline Variable effect & Original sample $(\mathrm{O})$ & P-value & Decision \\
\hline Stock market confidence $\rightarrow$ Stock market performance & 0.536 & 0.000 & H1 Accepted \\
\hline Investor's psychology $\rightarrow$ Stock market confidence & 0.419 & 0.000 & H2 Accepted \\
\hline Risk perception $\rightarrow$ Stock market confidence & 0.432 & 0.000 & H3 Accepted \\
\hline
\end{tabular}




\section{DISCUSSION}

The results show that the risk perception of the stock has a significant positive effect on stock market confidence. It means that the high risk perception in the investment in stocks will further boost investor's confidence in investing in the stock market. This study provides the empirical evidence that investors in Palembang when trading stocks understand the risks inherent to financial investments. Thus, the finding supports the first hypothesis (H1 is accepted).

On average, investors in Palembang have moderate risk characteristics. This type of investors belongs to long-term investors. This type of investors is deemed as rational investors meaning that the main purpose of the investment is longterm and has a high level of control and the tendency of selective observation (Natapura, 2009).

The findings (Takeda et al., 2013) show level literacy the of investment and individual investor's overconfidence in Japan with the number of respondents 533 men and women aged above 20 years and as investors showed that the level of literacy of high investment can lower overconfidence. Durand and Sanghani (2008) tested the relation between the level of investor personality that consists of individual extroverted and introverted in Australia. The finding reveals that individuals who have high emotion tend to take high risk or classified as risk taking affecting confidence in the performance of equity portfolios.

Table 11 reveals that investor's psychology has a significant positive effect on the level of con- fidence in the capital market. These finding demonstrates empirically that investor's psychology is reflected in the nature of cognitive, affective and cognative indicators is able to increase investor's confidence in the capital market. Psychology of investors is important, as it relates to the level of return that will be earned in the future. The findings of this study are in accordance with the theory of individual behavior in the context of the trilogy of mind (Hilgard, 1980; Mayer, 2001) that each behavior in decision making will be reflected in individual's psychology. Decisions under conditions of uncertainty or risk discussed in prospect theory that fairy individuals are associated with a range of decisions are clearly irrational (Kirmizi \& Agus, 2011; Subekti et al., 2010).

The finding proves that the level of confidence in capital markets has a significant positive effect on the performance of shares purchased by investors. Table 11 shows that coefficient of confidence level is 0.432 with positive direction indicating that investors in Palembang have a good level of confidence in investment in the capital market. The finding supports to the prospect theory (Kahneman \& Riepe, 1998; Takeda et al., 2013) that the investor's profit and loss is based on one specific point that the target return will be obtained. Number of total return in the decision to purchase and sell of shares obtained from periodic increase in dividend payments and capital gain so that the expectations of investors against this type of shares purchased are equal to the expected return. This study also supports a number of previous studies (Chuang, 2004; Seru et al., 2010; Shu et al., 2004).

\section{CONCLUSION AND FUTURE STUDIES}

The decision to purchase and sell common stock is affected the ability of the investor to manage the risk as a response to risk perception. This study proves that the understanding of risk perception is able to control the level of confidence in investing. Furthermore, investor's psychology about the nature of individual investors is reflected by the cognitive, affective, and cognative characteriticsis and is able to influence the level of convidence for stock investments. Both of these factors affect the decision of buying and selling stock which is reflected in dividend and capital gain as the total return. Future researches can be conducted again with research topic based on the concept of behavioral finance, because currently Indonesian capital market can be used as a source of revenue by individual with the risk that can be managed. 


\section{REFERENCES}

1. Barber, B. M., \& Odean, T. (2008). All That Glitters : The Effect of Attention and News on the Buying Behavior of Individual and Institutional Investors Graduate. The Review of Financial Studies, 21(2), 785-818. https://doi. org/10.1093/rfs/hhm079

2. Barber, B. M., \& Odean, T. (2001). Boys Will be Boys: Gender, Overconfidence, and Common Stock Investment. The Quarterly Journal of Economics, 116(1), 261292. Retrieved from http://www. jstor.org/stable/2696449

3. Barberis, N., Huang, M., \& Santos, T. (1999). Prospect Theory and Asset Prices. Cambridge, MA. https://doi.org/10.1017/ CBO9781107415324.004

4. Barberis, N., \& Thaler, R. H. (2002). A Survey of Behavioral Finance. SSRN Electronesearch, 15(1), 55-72. Retrieved from http://search.proquest. com/openview/504a51ea3f7b 233cecb020a9b91eb040/1?pqorigsite $=$ gscholar $\& \mathrm{cbl}=54566$

5. Chuang, S.-H., (2004). A resource-based perspective on knowledge management capability and competitive advantage: an empirical investigation. Expert Systems with Applications, 27(3), 459-465. https://doi.org/10.1016/j. eswa.2004.05.008

6. Du, D., (2012). Momentum and Behavioral Finance. Managerial Finance, 38(4), 364-379. http://dx.doi. org/10.1108/03074351211207527

7. Durand, R., \& Sanghani, J. (2008). An Intimate Portrait of the Individual Investor. Journal of Behavioral Finance, 9(44), 193-208. http://dx.doi. org/10.1080/15427560802341020

8. Grinblatt, M., \& Keloharju, M. (2001). What Makes Investors Trade ? The Journal of Finance, 56(2), 589-616. https://doi. org/10.1111/0022-1082.00338

9. Hilgard, E. R. (1980). The trilogy. Journal of the History of the Behavioral Sciences, 16, 107-117. https://doi.org/10.1002/15206696(198004)16:2<107::AIDJHBS2300160202>3.0.CO;2-Y

10. Hui, B., \& Li, P. (2014). Does Investor Sentiment Predict Stock Returns? The Evidence from Chinese Stock Market. J Syst Sci Complex, 27, 130-143. Retrieved from https://goo.gl/qvqqzs

11. Indonesia Stock Exchange. (2014). Siaran Pers. Retrieved from http:// www.idx.co.id/index.html

12. Kahneman, D., \& Riepe, M. W. (1998). Aspects of Investor Psychology. The Journal of Portfolio Management, 24(4), 52-65. https://doi.org/10.3905/ jpm.1998.409643

13. Kartika, N., \& Iramani, R. (2013). Pengaruh Overconfidence, Experience, Emotion terhadap Risk Perception dan Risk Attitude pada Investor Pasar Modal di Surabaya. Journal of Business and Banking, 3(2), 177-188. https://doi. org/10.14414/jbb.v3i2.235

14. Kirmizi, \& Agus, S. S. (2011). Pengaruh Pertumbuhan Modal dan Aset Terhadap Rasio Risk Based Capital (RBC), Pertumbuhan Premi Neto dan Profitabilitas Perusahaan Asuransi. Pekbis Jurnal, 3(1), 391-405. Retrieved from https://goo.gl/z4bXBN

15. Kumar, A. (2008). How Do Decision Choices Frames Influence the Stock Investors? Investment of Individual. Management Science, 54(6), 1052-1064. https://doi. org/10.1287/mnsc. 1070.0845

16. Linnainmaa, J. T. (2010). Do Limit Orders Alter Inferences about Investor Performance and Behavior? The Journal of Finance, 65(4), 1473-1506. https://doi.org/10.1111/j.15406261.2010.01576.x

17. Linnenluecke, M. K. et al. (2016). Emerging trends in Asia-Pacific finance research: A review of recent influential publications and a research agenda. Pacific Basin Finance Journal, 36, 66-76. http://dx.doi.org/10.1016/j.pacfin.2015.12.002
18. Lucey, B. M. (2005). The Role of Feeling in Investor DecisionMaking. Journal of Economic Surveys, 19(2), 212-237. https:// doi.org/10.1111/j.09500804.2005.00245.x

19. Maulina, V. (2011). Informasi Asimetri dan Periode Menahan Kepemilikan Saham Biasa di Bursa Efek Indonesia. Retrieved from Program Doktor Ilmu Manajemen Universitas Brawijaya Malang Jawa Timur.

20. Mayer, J. D. (2001). Primary Divisions of Personality and their Scientific Contributions : From the Trilogy-of-Mind to the Systems Set. Journal of the Theory of Social Behaviour, 31(4), 449-476. https://doi.org/10.1111/14685914.00169

21. Natapura, C. (2009). Analisis Perilaku Investor Institusional dengan Pendekatan Analytical Hierarchy Process (AHP), 16, 180187. Retrieved from http://journal. ui.ac.id/index.php/jbb/article/ viewFile/620/605

22. Odean, T. (2015). Trading Is Hazardous to Your Wealth : The Common Stock Investment Performance of Individual Investors. The Journal of Finance, 55(2), 773-806. https://doi. org/10.1111/0022-1082.00226

23. Qawi, R. B. (2010). Behavioral Finance : Is Investor Psyche Driving Market Performance? The IUP Journal of Behavioral Finance, VII(4), 7-20. Retrieved from http://search.proquest. com/openview/f6e118b15e4c d94d94d69a171ec73b88/1?pqorigsite $=$ gscholar $\& \mathrm{cbl}=54444$

24. Salge, T. O., Kohli, R., \& Barrett, M. (2015). Investing in Information Systems: On The Behavioral and Institutional Search Mechanisms Underpinning Hospitals' IS Investment Decisions. MIS Quartely, 39(1), 61-89. Retrieved from http://aisel.aisnet.org/misq/ vol39/iss1/6/

25. Seru, A., Shumway, T., \& Stoffman, N. (2010). Learning by Trading. 
The Review of Financial Studies, 23(2), 705-739. https://doi. org/10.1093/rfs/hhp060

26. Shu, P., Chen, H., \& Yeh, Y.-H. (2004). Does Trading Improve Individual Investor Performance? Review of Quantitative Finance and Accounting, 22, 199-217. https://doi.org/10.1023/ B:REQU.0000025760.91840.8d

27. Singh, M., Davidson, W. N., \& Suchard, J. (2003). Corporate diversification strategies and capital structure, 43, 147-167. https://doi.org/10.1016/S10629769(02)00124-2
28. Subekti, I., Wijayanti, A., \& Akhmad, K. (2010). The Real anc Accruals Earning Management: Satu Perspektif dari Teori Prospek, Simposioum Nasional Akuntansi XIII. Purwokerto.

29. Takeda, K., Takemura, T., \& Kozu, T. (2013). Investment Literacy and Individual Investor Biases: Survey Evidence in the Japanese Stock Market. Rev Socionetwork Strat, 7, 31-42. https://doi.org/10.1007/ s12626-012-0031-z

30. Worhington, A. (2006). Whether the Weather. A Comprehensive Assessment of Climate Effect in the Australian Stock Market. Retrieved from http://ro.uow.edu.au/commpapers/186/
31. Wulandari, D. A., \& Iramani, R. (2014). Studi Experienced Regret, Risk Tolerance, Overconfidence dan Risk Perception pada Pengambilan Keputusan Investasi Dosen Ekonomi. Journal of Business and Banking, 4(1), 55-66. Retrieved from https://journal. perbanas.ac.id/index.php/jbb/ article/viewFile/293/231

32. Yanti, M. (2012). Determinan Price Earning Ratio dan Stock Return (Studi pada Sahamsaham Syariah di Bursa Efek Indonesia). Retrieved from Universitas Brawijaya, Malang, Jawa Timur. 